\title{
Physical Quality, Proximate Composition and Trimethylamine Content of Clarias gariepinus (Cat Fish) Stored with Local Spices
}

\author{
Adamu Tuntuwa Jummai ${ }^{*}$, Charls Andrew Negbenebor ${ }^{2}$, Bamidele Joseph Okoli ${ }^{3}$ \\ ${ }^{1}$ National Biotechnology Development Agency, Federal Ministry of Science and Technology, Abuja, Nigeria \\ ${ }^{2}$ Department of Food Science and Technology, University of Maiduguri, Maiduguri, Nigeria \\ ${ }^{3}$ Department of Chemical Sciences, Bingham University, Karu, Nigeria \\ Email: *okolibj@binghamuni.edu.ng
}

How to cite this paper: Jummai, A.T., Negbenebor, C.A. and Okoli, B.J. (2016) Physical Quality, Proximate Composition and Trimethylamine Content of Clarias gariepinus (Cat Fish) Stored with Local Spices. Open Access Library Journal, 3: e2927.

http://dx.doi.org/10.4236/oalib.1102927

Received: September 7, 2016

Accepted: September 27, 2016

Published: September 30, 2016

Copyright $\odot 2016$ by authors and Open Access Library Inc.

This work is licensed under the Creative

Commons Attribution International

License (CC BY 4.0).

http://creativecommons.org/licenses/by/4.0/

\begin{abstract}
The objective of the study was to reduce post-harvest losses by developing a fish chub using Clarias gariepinus and to determine the effect of Monodora myristica (local nutmeg) and sorbitol on the physical quality, proximate composition and trimethylamine content of the product. Cooled smoked samples were packaged and stored at refrigerated and frozen storage conditions and examined for 1 - 12 weeks under frozen and $1-7$ days under refrigerated condition at intervals. The yield for the fish chub production was about $35 \%$, while $65 \%$ of the starting material was lost during processing. The protein content of the samples varied between $13 \%$ and $25 \%$. Frozen fish chubs stored at $-18^{\circ} \mathrm{C}$ had a shelf life of about six weeks while the refrigerated fish chub $\left(7^{\circ} \mathrm{C}-10^{\circ} \mathrm{C}\right)$ sample had a shelf life of about 4 days. The combined use of local nutmeg and sorbitol increased the shelf life under both storage conditions. The production of fish chub could be a viable economic venture in places where catfish is readily available and it is likely to improve protein intake of the consumers and reduce post-harvest losses.
\end{abstract}

\section{Subject Areas}

Aquaculture, Fisheries \& Fish Science

\section{Keywords}

Clarias gariepinus, Mondora myristica, Fish Chub, Sorbitol, Proximate Composition, Trimethylamine Content 


\section{Introduction}

Fish is an important source of protein. However, it is a highly perishable food, and this emphasizes the need for proper handling, processing and distribution. In view of the low and high nutritive value, the demand for fish is ever increasing and thus reduction in losses can make a major contribution to the fish market. Losses in cottage fisheries possess a great problem in the food production system of any country. The management and reduction of post-harvest loses require a prudent use of resources and reduction of spoilage, and convert raw materials into products for direct human consumption. To reduce fish spoilage, there is a need for improved fish handling, processing and distribution, all of which are deficient in Nigeria small-scale fisheries. Considerable quantity of fish is lost after being caught under warm moist prevailing in some parts of Nigeria. Spoilage can be rapid unless preventive actions are taken during the production/marketing chain. It has been reported that post-harvest losses in Nigeria constitute about $30 \%-55 \%$ of the total catch as a result of inadequate handling, storage and processing techniques leading to losses of between U\$\$123 - 220 million, which is about 17.8 naira annually [1].

Clarias gariepinus is a fish species that comes under the family Claridae and is in category "C". It is a fatty, fresh water fish. Although species of Clarias are not easy to identify because they all look similar, ten basic species have been described in Nigeria. Fish being highly nutritious contains about $60 \%-84 \%$ water, $0.1 \%-22 \%$ fat (depending on it is lean or fatty), $15 \%-24 \%$ protein, $1 \%-2 \%$ minerals and from negligible to $2 \%$ carbohydrate in addition to its richness in fat soluble vitamins especially vitamins A and D [2]. However, because fish is highly perishable, quality losses might occur very rapidly after harvest especially in hot climates and tropical areas where refrigeration facilities are inadequate. Also the methods of post-harvest handling have a degrading effect on the cumulative of the fish.

Fish spoilage following post-harvest losses as a result of inadequate handling, storage technique is on the increase in developing countries such as Nigerian, while at the same time protein malnutrition as a result of high costs of meat proteins is a common feature in this country. Developing a fish product such as (Japanese fish chubs) through the combine use of Mondora myristica and sorbitol will not only introduce new product to the domestic market, but also enhance protein intake and reduce protein malnutrition. This will also boost the revenue base of the fishermen as a result of reduced post-harvest losses of their products.

The aim of the study is to develop fish chub from Clarias gariepinus with an enhanced shelf life.

\section{Materials and Methods}

\subsection{Sources of Materials}

The fish samples Clarias gariepinus used for this study were obtained from Gamboru Maiduguri fresh fish market and transported to Food Science and Technology Department Laboratory and were then processed immediately. The fish samples were stored 
under frozen condition $\left(-18^{\circ} \mathrm{C}\right)$ in freezer before analysis. The spice Monodora myristica, common salt (Dicon salt), casing (small intestine of cow), sorbitol (Archer Daniels, Midland UK) were obtained from Monday Market Limited, Maiduguri.

\subsection{Preparation of the Spice}

The Monodora myristica (Figure 1) fruits were dehulled to remove the outer coat and processed as presented below and samples were wrapped in aluminium foil then autoclaved at 15 Psi $121^{\circ} \mathrm{C}$ ) for 15 minutes to destroy any microorganism present on the sample (Figure 2).

\subsection{Preparation of Fish Chubs}

The fish sample was thoroughly cleaned with $4 \%$ salt solution to remove the slime and to minimize contamination. The fish was weighed, headed, gutted, filleted and chopped into smaller sizes (about $20 \mathrm{~g}$ ). The fish sample was divided into 4 groups, each of the groups was treated separately as indicated below.

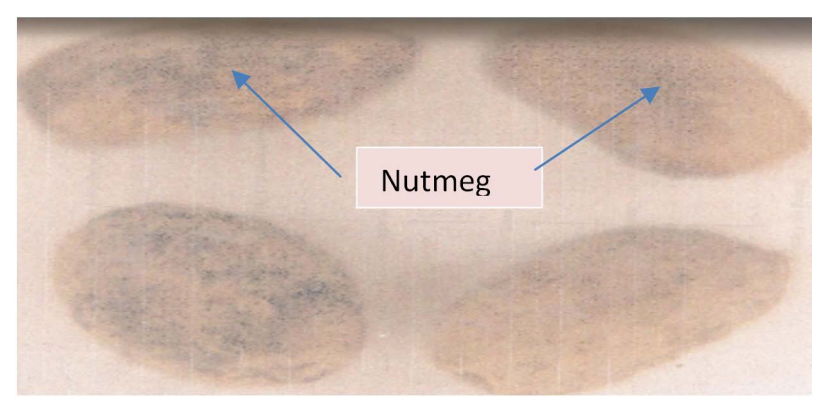

Figure 1. Dehuled Monodora myristica fruit.

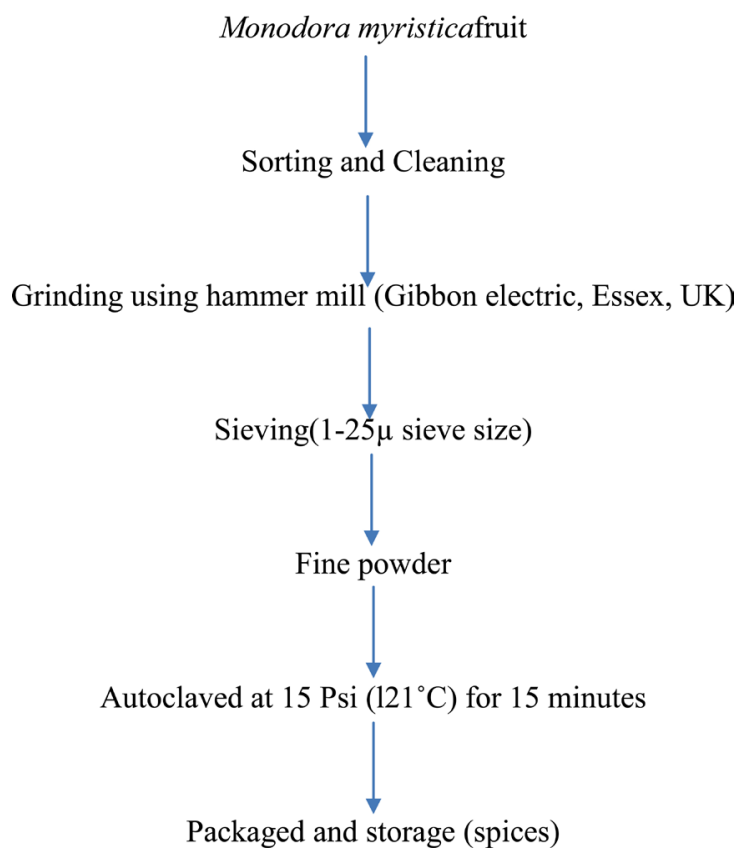

Figure 2. Flow diagram for the processing of the spice Manodom myristica. 
i) Control sample + Nitrate $(0.33 \%)+$ Salt $(1.5 \%)$.

ii) Sorbitol $(0.4 \%)+$ Nitrate $(0.33 \%)$ Salt $(1.5 \%)$.

iii) Nutmeg (Monodora myristica) $(0.2 \%)+$ Nitrate $(0.33 \%)+$ Salt $(1.5 \%)$

iv) A combination of (Monodora myristica) $(0.2 \%)+$ Sorbitol $(0.4 \%)+$ Nitrate $(0.33 \%)+$ Salt $(1.5 \%)[1]$.

The samples were cured for one hour separately and allowed to drain. The processing was carried out at ambient temperature of $28^{\circ} \mathrm{C}$ to $35^{\circ} \mathrm{C}$. The casing (small intestine of cow) was washed thoroughly with salt solution and cut to the desired length $(30 \mathrm{~cm})$. The fish was stuffed into the casing with the ends knotted with strings, then placed in a rack and smoked for six hours at $60^{\circ} \mathrm{C}$ (Figure 3). The product was cooled to room temperature. Packaged in polythene bag, separately and stored under refrigerated temperature at $7^{\circ} \mathrm{C}-10^{\circ} \mathrm{C}$ for 1 week, and frozen temperature of $-18^{\circ} \mathrm{C}$ for 12 weeks for quality determinations. The samples were analysed for yield, physical quality, proximate composition and trimethylamine content at predetermined intervals. The frozen samples were analysed at week 0,2 , and every two weeks for a period of 12 weeks, while the refrigerated samples were analysed at day 0,1 , and every day for a period of 7 days.

\subsection{Experimental Design}

The experimental design was factorial arrangement with $4 \times 2$ treatments. The fixed factors were sample treatment consisting of control, Nutmeg, sorbitol and mixed Nutmeg and treatments. The variable factors were refrigeration (1 - 7 days) and deep freezing 1 - 12 weeks).

\subsection{Physical Parameters}

The length, width and weight of the fish were determined and bones evaluated using electronic (Toludo Midland) weighing balance. The total percentage yield was determined as the weight of processed product divided the weight of the raw material multiplied by 100 .

\subsection{Proximate Analysis}

The methods used for the proximate analysis were standard methods described by the

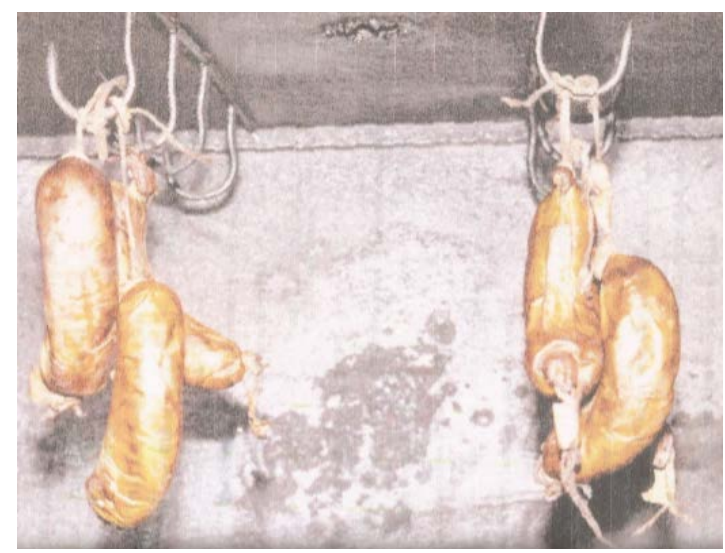

Figure 3. Fish chub in a casing under smoking process in a kiln. 
Association of Official Chemists [3].

\subsection{Sample Preparation for Trimethylamine Determination}

Principle: Foodstuff serves as a good media for growth of many different microorganisms. During growth these organisms will produce changes in appearance flavour, odour and qualities. The degradation process may be outlined as follows:

$$
\text { Protein food + proteolytic } \rightarrow \begin{gathered}
\text { Amino acids }+ \text { Amine }+\mathrm{NH}_{3}+\mathrm{H}_{2} \mathrm{~S} . \\
\text { Enzymes of microorganism(trimethlyamine) }
\end{gathered}
$$

The amines extracted into trichloroacetic acid and toluene after which it is reacted with picric acid and the pink colour developed is determined spectrophotometrically.

\section{Calculation}

$$
\frac{A}{A^{1}} \times\left(\text { mg TMA }-\mathrm{N} / \mathrm{ml} \text { Std. Solution } \times \mathrm{ml} \text { of std solution } \times 300 \mathrm{~A}^{1}\right)
$$

where $\mathrm{A}$ and $\mathrm{A}^{1}$ are absorbances of the sample and standard respectively.

\subsection{Storage Studies Determinations}

Samples were packed in polythene bags separately knotted and the storage studies were carried out for the samples during storage at refrigerated and frozen temperatures. Samples were analysed every two weeks for physical quality, proximate composition and trimethylamine content for three months period to determine the shelf life, and refrigerated samples were analysed day 0,1 and every day for a period of 7 days.

\subsection{Statistical Analysis}

All data for statistical analysis were subjected to analysis of variance (ANOVA) as described by Amerine [4]. The differences between means were determined using Duncans multiple range test (DMRT) as described by Gomez and Gomez [5].

\section{Results and Discussion}

\subsection{Yield of Fresh for Fish Chub Preparation}

The fish used in this study had mean weight of $514 \pm 5.8 \mathrm{~g}$ and length and width of 34.8 and $5.3 \mathrm{~cm}$ respectively (Table 1 ). Fish of this size is common in fish market especially during the rainy season. The maximum length of this fish could be up to 1 metre [6]. The yield of the fish was only about $35 \%$ and consequently about $65 \%$ of the material during processing. The low yield may have been because the head constitutes more of the body weight of the fish. The yield, after the removal of the head, fins and were $38.91 \%, 37.88 \%, 34.61 \%$ respectively.

\subsection{Yield of Processed Chubs}

The yield of the treated fish chubs ranged from $93.19 \%$ to $93.64 \% \pm 1.20 \%$ while that of the control sample was $91.21 \%$ (Figure 4). Result indicated that the treated sample had 
Table 1. Yield and physical characteristics of fish (Clarias gariepinus) used for fish chub preparation.

\begin{tabular}{ccc}
\hline & Grams $(\mathrm{g})$ & Percentage yield (\%) \\
\hline Weight of whole fish & $514 \pm 5.8$ & 38.91 \\
Weight after removal of head & $200 \pm 2.3$ & 37.88 \\
Weight after removal of fins & $194.7 \pm 4.8$ & 34.61 \\
Weight after removal of bones & $177.9 \pm 1.2$ & \\
Mean length of fish $(\mathrm{cm})$ & $34.8 \pm 1.2$ & \\
Mean width $(\mathrm{cm})$ & $5.2 \pm 0.5$ & \\
\hline
\end{tabular}

Mean \pm SD of triplicate determinations

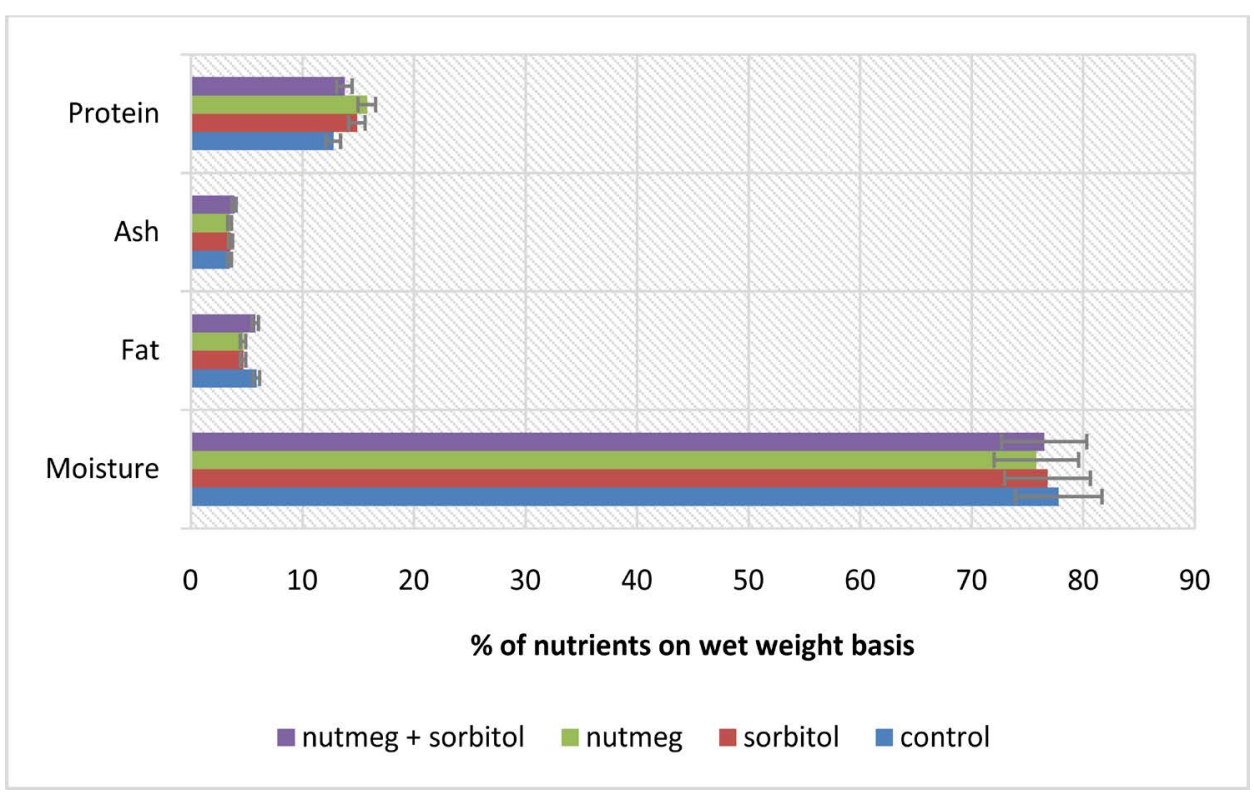

Figure 4. Proximate composition of unsmoked fish chub from Clarias gariepinus.

higher $(\mathrm{p}<0.05)$ percentage yield when compared to the control however, there was no difference among the treated samples. Result suggests the ability of the treatments to bind moisture and reduce smoking purge. Yield is an important factor, which must be in the development of fish chubs for marketing [7]. The various treatments might also have interacted with the proteins leading to different rate of protein denaturation [8], and hence the space available on the protein for binding of the moisture.

\subsection{Proximate Composition}

\subsubsection{Unsmoked Fish Chub}

The moisture content of the control sample was $77.8 \% \pm 0.2 \%$ (Figure 1 ). The sample treated with different spices showed moisture content which ranged from $75.8 \% \pm 0.4 \%$ to $76.8 \% \pm 0.3 \%$, ash content ranged from $3.5 \% \pm 0.3 \%$ to $3.9 \% \pm 0.3 \%$, fat content ranged $47 \% \pm 0.2 \%$ to $5.9 \% \pm 0.3 \%$ and protein content ranged from, $12.8 \% \pm 0.7 \%$ to $15.8 \% \pm 0.4 \%$ (Figure 1 ). 
The moisture content obtained in this study for the processed samples is similar to that reported by Negbenebor [1], who reported a moisture content which ranged $63.8 \%$ to $77.3 \%$ in Clarias angullaris.

There was significant decrease $(\mathrm{P}<0.05)$ in moisture and fat contents, but an increase 0.05 ) in ash and protein content of the processed products when compared with the raw (Figure 4). The lower moisture content of the processed sample when compared with the control sample may be due to shrinkage and loss of water as a result of heat applied the sample during smoking [1]. The increase in the amount of protein suggests a concentration of nutrients in which was due to loss in moisture content of the main product (i.e. fish chub).

\subsubsection{Smoked Fish Chub}

The moisture content of the smoked samples was about $66.8 \%$ and it is lower than $9 \%$ reported by Hastings [9] for fresh whiting. Heat generated during smoking may have been responsible for the dehydration of the samples. The variation in moisture content may be due to specie differences and the method of processing [1]. The smoked sample had an ash content which ranged from $5.7 \%$ to $5.9 \%$, fat content which ranged from $4.5 \%$ to $4.8 \%$ and crude protein ranged from $22.8 \%$ to $24.8 \%$ (Table 1 ).

All treated samples had higher fats content than the control. Sorbitol or nutmeg may have protected the fat during the processing. In case of ash no significant difference were observed $(\mathrm{P}>0.05)$ irrespective of the method of treatment suggesting that the treatment did not have any protective effect on the ash during processing. (Figure 5)

\subsection{Changes in Trimethyiamine}

Figure 6 showed the effect of sorbitol and Nutmeg on trimethyiamine values of the processed fish chub stored under frozen temperature. Following processing (at week

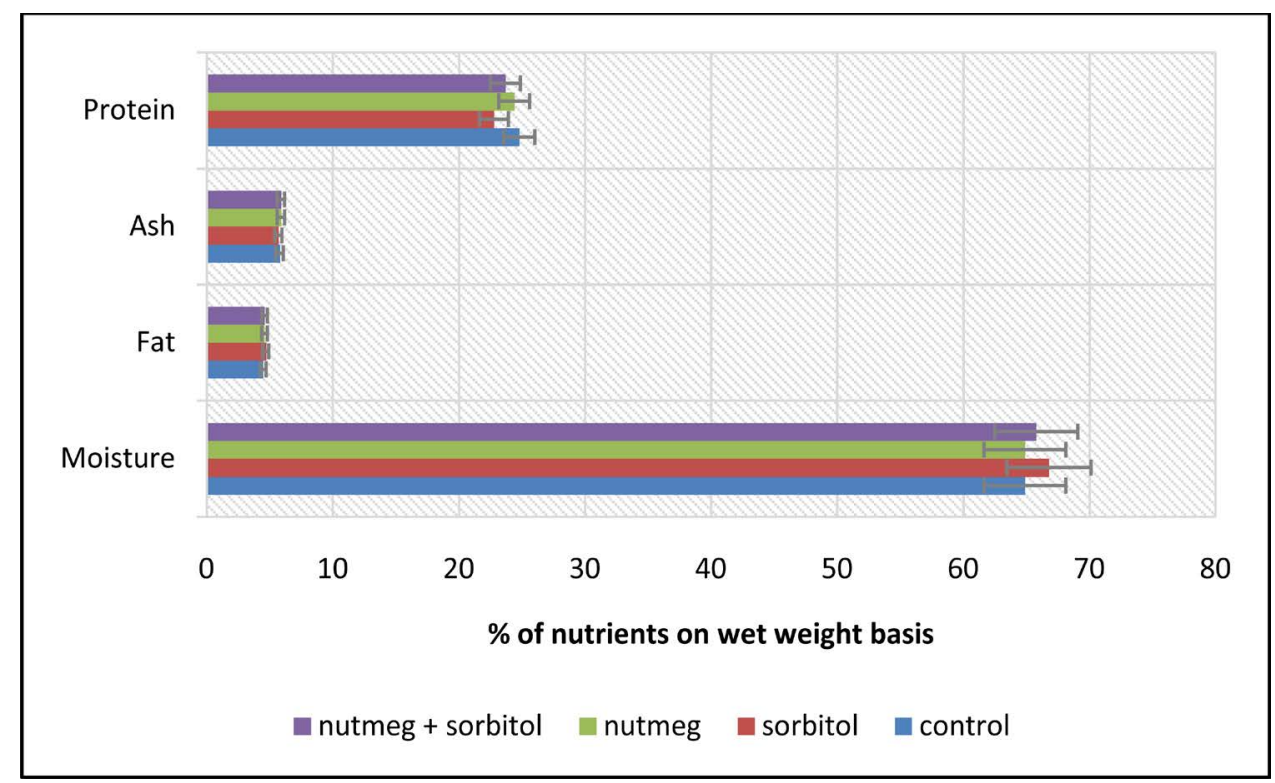

Figure 5. Proximate composition of smoked fish chub from Clarias gariepinus. 


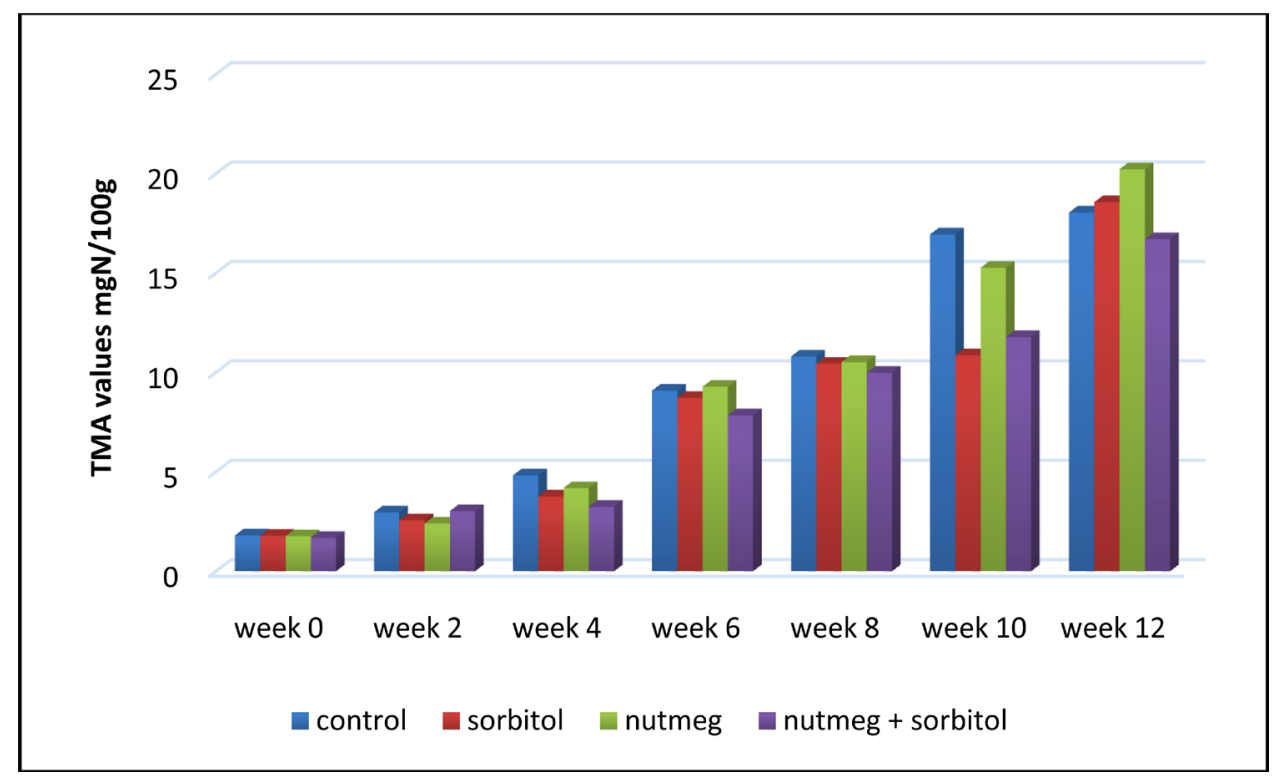

Figure 6. Effect of Monodora myristica and sorbitol on trimethylamine value $\mathrm{mgN} / \mathrm{l00g}$ of fish chub stored at frozen temperature $\left(-18^{\circ} \mathrm{C}\right)$ for 12 weeks.

' 0 ') samples treated with Nutmeg + sorbitol under frozen storage had the lowest trimethylamine value of $1.68 \mathrm{mgN} / 100 \mathrm{~g}$ tissues when compared to the other treated samples and the control (Figure 6). The values of trimethylamine value at week ' 0 ' ranged from $1.68 \mathrm{mgN} / 100 \mathrm{~g}$ to $1.80 \mathrm{mgN} / 100 \mathrm{~g}$ tissues. Data suggest that a combination of Nutmeg + sorbitol treatment had greater inhibitory effect on trimethylamine production on week ' 0 ' during frozen storage when compared to the other treatments and the control. After six weeks of storage under frozen temperature, the trimethylamine values were from $7.84 \sim 9.38 \mathrm{mgN} / 100 \mathrm{~g}$ tissue and were within acceptable range. According to Marozo and Curti [10], trimethylamine levels between 5 and $10 \mathrm{mgN} / 100 \mathrm{~g}$ tissues is considered the maximum allowable levels in international trading. After 12 weeks of storage, a combination of Nutmeg + Sorbitol treated samples had the least values of TMA. These trimethylamine values ranged from 16.70 to $20.22 \mathrm{mgN} / 100 \mathrm{~g}$ tissues. Such high values are unacceptable by international standards.

The trimethylamine value obtained in this study (i.e. frozen temperature) was lower than that earlier reported by Negbenebor [1], for washed minced fish and Kamaboko-type product. The differences in trintethylamine values might be as a result of product-type, method of processing and storage conditions. The result suggests that the addition of the spices did not completely inhibit the production of production of trimethylarnine during the storage process. The ability of the treatment to inhibited trimethylarnine production may be due to the ability of the nutmeg + sorbitol to inhibited multiplication of the microorganism.

Generally, the storage or fish chub at frozen temperature was considered far better than that of the refrigerated temperature. For the refrigerated samples, the TMA values ranged from 1.98 - $26.88 \mathrm{mgN} / 100 \mathrm{~g}$ after 12 days of storage (Figure 7) because of lower TMA values at this temperature. Increase in the trimethylamine value might be as a re- 


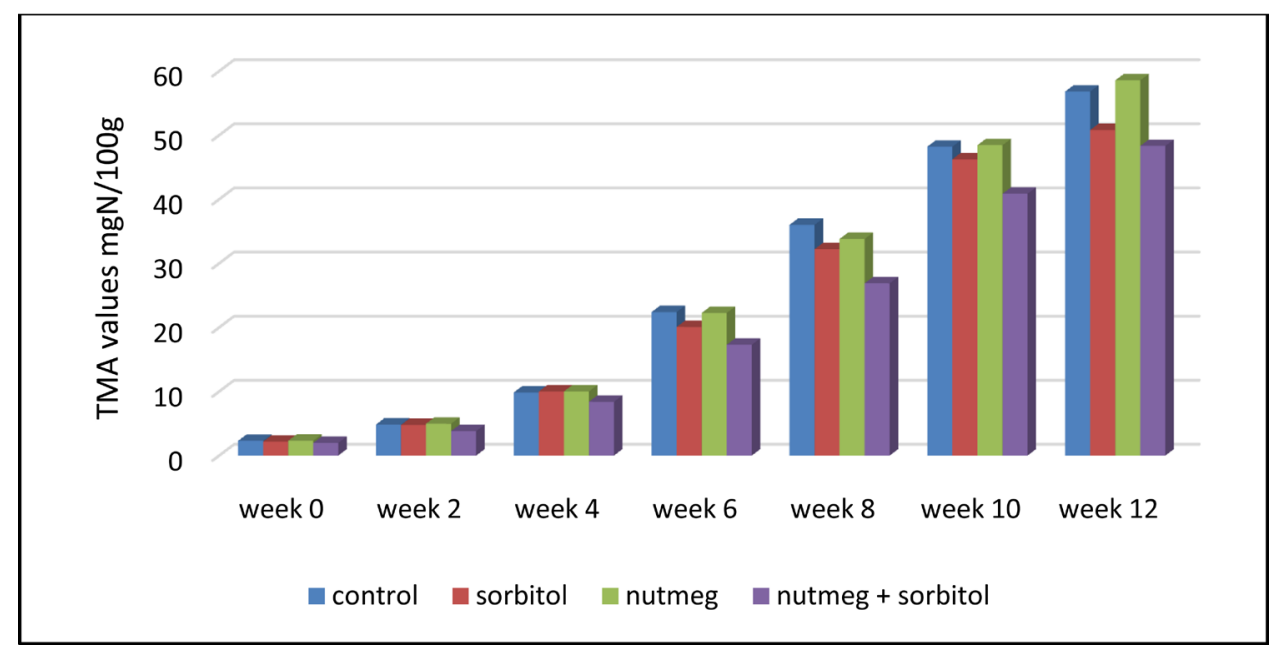

Figure 7. Changes in trimethylamine content of refrigerated fish chub.

sult of higher temperature of the refrigerator compared to the freezer [10].

The higher the trimethylamine value the lower the quality of the fish chub, and the lower the trimethylamine value the better the quality of the fish sample [11]. TMA values of the samples were acceptable after 4 days of refrigeration, while those stored at frozen temperature for six weeks were still acceptable. This is in line with the observation of Marzo and Curti [10].

Several food grade antioxidants and metal chelators such as sodium citrate, poly phosphate and sodium citrate alone or in combination have been used to maintain quality and increase the shelf life of fish by inactivating enzymes and chelating metals [12]. It is possible that such enzyme inactivation and chelation of metals by sorbitol and nutmeg may be partially responsible for the decrease in TMA values. In addition, fatty oil of nutmeg contains $12 \%$ myristin, the glyceric ester of myristic acid, stearic acid and oleic acids [13]. These may have assisted in inhibiting the TMA values of the fish chubs during storage.

\section{Conclusions}

Considering the loss of $65 \%$ during process, it may be advisable if the wastes (i.e. head of the fish, fins and bones) are dried, ground and used as component of fishmeal for animal feed. Such meals will be rich in protein and calcium. From an economic point of view, the revenue, which accrued from the sales of the dried ground waste could supplement the cost of production and lower the cost of the fish chub, thereby making the fish chub affordable to the poor.

The use of local nutmeg and sorbitol during processing did not lead to any appreciable loss of nutrients. In fact, this food additive enhances dehydration, which leads to an increase in density or concentration of the nutrients and salt in the fish chub. The heat generated during smoking is partly responsible for the dehydration of the product. The average weight of a fresh fish chub was about $180 \mathrm{~g}$, on dry weight basis. This furnished about $36 \mathrm{~g}$ of fish chub and about 20 - $25 \mathrm{~g}$ of protein. The protein requirement of chil- 
dren from ages 1 - 10 varies from 16 - 20 g per day [14]. This would imply that an average fish chub of $180 \mathrm{~g}$ would meet the requirement of these children (i.e. 1 - 10) who incidentally are the most susceptible to protein energy malnutrition. It could also be deduced that two or three pieces of fish chubs of average sizes are enough to meet the requirement of adult and particularly the pregnant, lactating women, including the elderly who fall within the vulnerable groups.

The shelf life of a perishable product such as a fish chub is a very important feature for the quality assurance and marketing of the product. Since the product is not likely to get to the consumer on the day of the manufacture, the overall assessment of the shelf life by trimethylamine determinations shows that the product can only last for 8 weeks at $-18^{\circ} \mathrm{C}$. That is taking into consideration that $10 \mathrm{mgN} / 100 \mathrm{~g}$ is the upper limit for TMA by international standards [10]. Therefore, a continuous supply of electricity to maintain deep freezers will be crucial to the success of a fish chub enterprise. The possibility of using dry ice for this purpose may also be considered in the absence of constant power supply.

If the product is refrigerated $7^{\circ} \mathrm{C}-10^{\circ} \mathrm{C}$, then it will only last for 4 days going by the same standards earlier mentioned. Therefore, it may be advisable for retailers of fish chubs to keep the products in a frozen condition $\left(-18^{\circ} \mathrm{C}\right)$. While consumers who are likely to have refrigerated sample should be well informed about the expiring date. Thus consumers may be advised to consume the products within 4 days after purchase or processing.

The deterioration of fats in the fish chub deserves a special attention since there is an increase during refrigeration. However, the rancidity of the unsaturated fatty acids in the fish should receive a greater attention. Although rancidity test was not carried out in this project, it will be interesting to investigate if any of the additives i.e. sorbitol or local nutmeg has antioxidant value in the stored products. If found negative there may be the need to add antioxidant, particularly natural ones such as Vitamin C, Vitamin E or $\mathrm{B}$ carotene (Provitamin A). In fact, the processing of the fish chub with $\beta$ carotene will be an added advantage since protein malnutrition is strongly linked with Vitamin A deficiency.

An ideal fish chub product could be developed from catfish (Clarias gariepinus). The processing involves the use of common salt, sodium nitrate, sorbitol and a local nutmeg spice from Monodora myristica. The production of fish chub is a viable economic venture in places where catfish can be easily sourced and it is likely to improve protein intake by low-income earner. The introduction will increase the number of fish products available to the consumers in the Nigerian market.

\section{References}

[1] Negbenebor, C.A., Godiya, A.A. and Igene, J.O. (1999) Evaluation of Clarias anguillains Treated with Spice (Piper guinnense) for Washed Mice and Kama Book Type Product. Journal of Food Composition and Analysis, 12, 315-322.

[2] Clucas, I.J. and Ward, A.R. (1996) Preservation, Processing and Quality Chathan Maritime. $443 \mathrm{p}$. 
[3] AOAC (1984) Official Methods of Analysis. 14th Edition, Association of Analytical Chemists, Washington DC, 249-252.

[4] Amerine, A.M. Pagham, A.M. and Poster, E.B. (1965) Principles of Sensory Evaluation in Food. Academic Press, London

[5] Gomez, K.A. and Gomez, A.A. (1984) Statistical Procedure for Agriculture Research. 2nd Edition, John Willey and Sons, New York.

[6] Olaosebican, B.D. and Raji, A. (1998) Nigerian Fresh Water Fisheries. 978-934.

[7] Yi, Y.H. (1986) Studies on the Quality of Profiled Chicken Patties during Refrigerated Storage. PhD Dissertation, Mississippi State University, Starkville.

[8] Love, B.E. and Godwin, T.C. (1974) Effects of Cooking Methods and Browning Temperatures on Yield of Poultry Parts. Poultry Science, 53, 1391-1393.

http://dx.doi.org/10.3382/ps.0531391

[9] Hastmgs, R.S., Keary, J.N. and Young, K.W. (1990) The Properties of Surimi and Kamaboko Gels from and British Species of Fish. International Journal of Food Science \& Technology, 25, 281-294.

[10] Marzo, A. and Curti, E. (1997) Reappraisal Covering the Commonest Methods C-Hromotogr 702 .

[11] Dalgaard, J.Z. (1993) Crystallizations and Preliminary Crystallographic Analysis of the Archaeal Intron-Encoded Endonuclease I-DmoI. Acta Crystallographica Section D, 54, 1435 1436.

[12] Anonymous (1991) The Surumi Squeeze. Sea Food Business, 10, 37-42.

[13] Stein, U., Greyer, H. and Hentschel, H. (2001) Nutmeg (Myristica) Poisoning-Report on a Fatal Case and a Series of Cases Recorded by a Poison Information Centre. Forensic Science Internationa, 118, 87-90.

[14] FAO/WHO (1973) Joint Expert Committee on Energy and Protein Requirement. Technical Report Series No. 522, WHO, Geneva.

\section{Submit or recommend next manuscript to OALib Journal and we will provide best} service for you:

- Publication frequency: Monthly

- 9 subject areas of science, technology and medicine

- Fair and rigorous peer-review system

- Fast publication process

- Article promotion in various social networking sites (LinkedIn, Facebook, Twitter, etc.)

- Maximum dissemination of your research work

Submit Your Paper Online: Click Here to Submit

Contact Us: service@oalib.com 